\title{
Debido proceso y presunción de inocencia: una propuesta para el Derecho administrativo sancionador
}

\section{Due process and presumption of innocence: a proposal for administrative law sanctions}

Emilio Boutaud Scheuermann*

El artículo examina la aplicación del derecho a la presunción de inocencia, en tanto elemento del debido proceso penal, en los procedimientos administrativos sancionadores. Con dicho fin, por un lado, se expone la jurisprudencia de la Corte Interamericana de Derechos Humanos y el Tribunal Constitucional sobre el denominado "debido proceso administrativo" y se propone cuál debería ser su contenido mínimo en los procedimientos administrativos sancionadores. Por otro lado, se revisan los orígenes y principales significados de la presunción de inocencia (regla de trato, regla sobre la distribución de la carga de la prueba y regla sobre el estándar de prueba), los planteamientos de la doctrina nacional y la jurisprudencia constitucional sobre su aplicación en sede administrativa y las objeciones
The article examines the application of the presumption of innocence, as an element of criminal due process, in administrative sanctioning procedures. To this end, the jurisprudence of the Inter-American Court of Human Rights and the Constitutional Court on the so-called administrative due process is presented and it is proposed what its minimum content should be in administrative sanctioning procedures. Then, the origins and main meanings of the presumption of innocence are reviewed (rule of treatment and rule on the burden of proof), the approaches of the national doctrine and the constitutional jurisprudence on its application in administrative matters and the objections that can be formulated to this thesis. It is concluded that, despite these objections, the main meanings of

\footnotetext{
* Abogado. Doctorando en Derecho, Universidad Austral de Chile. Correo electrónico: emilioboutaud@gmail.com. Dirección postal: Mac-Iver 985, Paillaco, Región de Los Ríos, Chile.

1 Esta investigación cuenta con el apoyo financiero de la beca otorgada por la Comisión Nacional de Investigación Científica y Tecnológica, CONICYT-PFCHA/Doctorado Nacional/2019, N²1191443. El autor agradece especialmente las observaciones de Víctor García Yzaguirre a una versión preliminar de este texto, y las aportaciones de los árbitros que han contribuido al mejoramiento del presente artículo.
}

Artículo recibido el 21 de mayo de 2021 y aceptado el 10 de diciembre de 2021 . 
que pueden formularse a esta tesis. Se concluye que, a pesar de estas objeciones, los principales significados de la presunción de inocencia deberían ser aplicados "con matices" en los procedimientos administrativos sancionadores, esto es, manteniendo la esencia o núcleo de este derecho y alterando solo sus aspectos secundarios.

Palabras clave: debido proceso, presunción de inocencia, procedimientos administrativos sancionadores. the presumption of innocence must be applied with nuances in administrative sanctioning procedures, that is, maintaining the core of this right and altering only its secondary aspects.

Keywords: due process, presumption of innocence, administrative sanctioning procedures.

\section{Introducción}

La protección de los derechos fundamentales de las personas frente a la actividad del Estado se ha incrementado ostensiblemente en las últimas décadas. Así, en el marco de la jurisprudencia de la Corte Interamericana de Derechos Humanos (Corte IDH), se ha discutido acerca de si el derecho al debido proceso debería aplicarse o no a la actividad desarrollada por los órganos de la Administración del Estado, especialmente cuando ejercen su potestad sancionadora. La Corte IDH ha sostenido, de manera general, que sí resulta exigible el debido proceso en los procedimientos administrativos sancionadores $^{1}$. En el mismo sentido se ha pronunciado el Tribunal Constitucional (TC) con base en la teoría del ius puniendi único, según la cual los principios penales son aplicables con matices en el derecho administrativo sancionador ${ }^{2}$. Es decir, para estos tribunales los particulares tendrían derecho a un debido proceso administrativo, especialmente cuando se les aplican sanciones.

Sin embargo, dado que no es adecuado realizar una aceptación acrítica de las tesis jurisprudenciales precedentes, esta afirmación general sobre la aplicabilidad del debido proceso en los procedimientos administrativos sancionadores requiere numerosas precisiones. Al respecto debe considerarse que el contenido del derecho al debido proceso adolece de un alto grado de indeterminación y que sus exigencias en el ámbito penal son mayores que en otras sedes jurisdiccionales. Por ello, cabe preguntarse, por ejemplo, si el debido proceso impone las mismas exigencias tanto ante los tribunales de justicia como ante los órganos administrativos (competencia, independencia, imparcialidad, etc.), o si los órganos administrativos, al ejercer su potestad sancionadora, deben respetar todas las exigencias del debido proceso penal (presunción de inocencia, publicidad, asistencia letrada, etc.).

\footnotetext{
1 Caso Baena Ricardo y otros vs. Panamá (2001); Caso Ivcher Bronstein vs. Perú (2001); Caso Vélez Loor vs. Panamá (2010).

2 Sentencia TC Rol Nº 437 (2005); Sentencia TC Rol № 2264 (2013).
} 
En el marco de esta discusión, el presente artículo pretende reflexionar y realizar una propuesta sobre la aplicación del derecho a la presunción de inocencia en los procedimientos administrativos sancionadores. En el derecho chileno, la presunción de inocencia es una garantía prevista explícitamente, con ocasión del debido proceso penal, en el artículo 8.2 de la Convención Americana de Derechos Humanos $(\mathrm{CADH})^{3}$, tratado internacional que, de conformidad con el artículo 5 inciso segundo de la Constitución (CPR) constituye un límite al ejercicio de la soberanía y debe ser respetado por todos los órganos del Estado, incluida la Administración. En el ámbito penal, la presunción de inocencia posee diversos significados o manifestaciones, entre ellas, es una regla de trato, una regla sobre la distribución de la carga de la prueba y una regla de juicio o sobre el estándar de prueba ${ }^{4}$.

En sede administrativa, en cambio, no hay una disposición internacional, constitucional o una ley general que se refiera al punto, pese a lo cual, en general, la doctrina mayoritaria y la jurisprudencia se han mostrado favorables a la vigencia de la presunción de inocencia en los procedimientos sancionadores. Sin embargo, no ha habido una acuciosa reflexión sobre la materia. Prueba de ello, es que tanto la doctrina como la jurisprudencia han esgrimido como singular y gran argumento a favor de la aplicabilidad de la presunción de inocencia en el derecho administrativo sancionador la tesis del ius puniendi único, sin especificar a cuál o cuáles de los significados de este derecho se refieren.

Frente a esta situación, el presente artículo pretende sustentar la vigencia de las principales manifestaciones de la presunción de inocencia en el derecho administrativo sancionador, y determinar el contenido de los matices en su aplicación, a la luz de la vinculación de la presunción de inocencia con el derecho al debido proceso. El trabajo se estructura en dos partes. En la primera sección se expresan algunos cuestionamientos a la jurisprudencia de la Corte IDH y el TC sobre la aplicación del derecho al debido proceso en sede administrativa y se propone cuál debería ser su contenido mínimo en los procedimientos administrativos sancionadores. En la segunda sección se distinguen tres significados o manifestaciones de la presunción de inocencia (regla de trato, regla sobre la distribución de la carga de la prueba y regla sobre el estándar de prueba), se exponen los planteamientos de la doctrina nacional y la jurisprudencia constitucional sobre su aplicación en sede administrativa y se procura superar algunas objeciones que pueden formularse a esta tesis. Finalmente, se propone que estos significados de la presunción de inocencia deberían ser aplicados "con matices" en los procedimientos administrativos sancionadores, al mismo tiempo que se precisa en qué consistirían estos.

\footnotetext{
${ }^{3}$ Ratificada por Chile con fecha 8 de octubre de 1990 y publicada en el Diario Oficial el día 5 de enero de 1991.

4 Ferrer Beltrán 2010, 5-23; Fernandez López 2004, 209-249.
} 


\section{El debido proceso y las sanciones administrativas}

La discusión sobre la presunción de inocencia en los procedimientos administrativos sancionadores se inserta dentro de un debate más amplio referido a la aplicación del derecho al debido proceso en los procedimientos administrativos. Por ello, previo a analizar la eventual aplicación de la presunción de inocencia en el derecho administrativo sancionador, se revisará el estado de la discusión sobre el debido procedimiento administrativo en la jurisprudencia constitucional e interamericana y se fijará una posición al respecto. Luego, se plantearán lineamientos generales sobre el debido procedimiento administrativo sancionador.

\section{El debido proceso en la jurisprudencia constitucional e interamericana}

Aunque nuestra Constitución no emplea la expresión debido proceso ${ }^{5}$, este derecho se entiende reconocido como un derecho fundamental en el artículo 19 número 3 inciso sexto $\mathrm{CPR}^{6}$. Este precepto prescribe la necesidad de racionalidad y justicia en las investigaciones y los procedimientos y el correlativo deber del legislador de establecer siempre estas garantías. A su vez, los tratados internacionales ratificados por Chile y vigentes consagran ciertas garantías que forman parte del contenido del debido proceso, tales como el derecho a ser oído por un tribunal competente, independiente e imparcial ${ }^{7}$ y el derecho a un recurso efectivo ${ }^{8}$.

En Chile el debido proceso también hace referencia a un principio constitucional ${ }^{9}$ que permite al legislador y a los jueces expandir tanto su contenido como su ámbito de aplicación ${ }^{10}$. Precisamente, a partir del tenor literal tanto del artículo 19 número 3 inciso sexto CPR como del artículo $8.1 \mathrm{CADH}$, la jurisprudencia nacional e interamericana ha expandido el ámbito de aplicación

\footnotetext{
${ }^{5}$ En el acta de la sesión 101 de la Comisión de Estudios de la Nueva Constitución consta la razón de la no utilización del vocablo debido proceso. El comisionado Evans sostuvo que, si empleaba esta expresión los intérpretes, la jurisprudencia, los tratadistas y abogados, eventualmente podrían quedar obligados a un estudio exhaustivo de la doctrina y la jurisprudencia anglosajona. Comisión de Estudios de la Nueva Constitución 1975 tomo III, 516.

6 Nogueira Alcala 2003, 169.

7 El artículo 8.1 de la Convención Americana de Derechos Humanos dispone que: "Toda persona tiene derecho a ser oída, con las debidas garantías y dentro de un plazo razonable, por un juez o tribunal competente, independiente e imparcial, establecido con anterioridad por la ley, en la sustanciación de cualquier acusación penal formulada contra ella, o para la determinación de sus derechos y obligaciones de orden civil, laboral, fiscal o de cualquier otro carácter". En idéntico sentido el artículo 14 del Pacto Internacional de Derechos Civiles y Políticos.

8 El artículo 25 de la Convención Americana de Derechos Humanos establece que: "Toda persona tiene derecho a un recurso sencillo y rápido o a cualquier otro recurso efectivo ante los jueces o tribunales competentes, que la ampare contra actos que violen sus derechos fundamentales reconocidos por la Constitución, la ley o la presente Convención, aun cuando tal violación sea cometida por personas que actúen en ejercicio de sus funciones oficiales".

9 Bordali Salamanca 2010, 92; Zapata Larraín 2008, 568.

10 Bordalí Salamanca 2016, 200.
} 
del derecho al debido proceso hacia los procedimientos administrativos ${ }^{11}$. Para ello, estos organismos han empleado diversas justificaciones, las cuales, como se expondrá a continuación, no son del todo satisfactorias y no pueden aceptarse acríticamente por aplicación de un argumento de autoridad ${ }^{12}$.

El TC ha hecho extensivo el debido proceso a los órganos de la Administración del Estado, en general, por considerar que se trata de órganos que ejercen jurisdicción. A su juicio, las garantías del debido proceso se encuentran establecidas en relación con el ejercicio de la función jurisdiccional, independiente del órgano que la ejerza. Luego, no solo los tribunales ejercerían jurisdicción, sino que también otros órganos que integran la Administración del Estado, pues resolverían situaciones que afectan a las personas y sus bienes ${ }^{13}$.

Eso sí, en materia de sanciones administrativas, el TC ha modificado esta línea argumental precisado que, aun cuando la potestad para aplicar, rebajar o condonar sanciones no supone el ejercicio de la jurisdicción, debe igualmente sujetarse a los parámetros propios de un debido proceso ${ }^{14}$. El fundamento de esta aserción ha sido la teoría del ius puniendi según la cual las penas y las sanciones administrativas tendrían un origen común; por lo tanto, en los procedimientos administrativos sancionadores resultarían aplicables con matices las garantías penales sustantivas y procedimentales, entre ellas, el debido proceso ${ }^{15}$.

En esa línea, el TC ha fijado el contenido mínimo del debido procedimiento administrativo sancionador al manifestar que:

A la imposición de sanciones administrativas, pues, necesariamente debe anteceder una serie concatenada de trámites, tan esenciales como un acta o acusación o formulación de cargos precisa y sostenida en una

\footnotetext{
11 Esta expansión tiene como antecedente el derecho estadounidense en el que se distingue entre el debido proceso procesal y el debido proceso sustantivo. El debido proceso procesal está dirigido a los tribunales de justicia y exige el respeto de ciertos derechos procesales de las partes tales como el derecho a un juez natural, el derecho a ser juzgado en un plazo razonable, la publicidad del procedimiento, entre otros. Mientras que el debido proceso sustantivo está dirigido a restringir la actuación del legislador y de la Administración del Estado, proscribiendo la limitación o privación arbitraria de derechos fundamentales de las personas. Williams 2010, 417-419; Esparza LEIBAR 1995, 75.

12 Cabe recordar que en el ámbito interamericano la Corte IDH ha desarrollado la doctrina del control de convencionalidad, según la cual su jurisprudencia (aunque un Estado no haya sido parte en la causa) y su interpretación de la CADH son vinculantes para todos los órganos de los Estados que han ratificado dicho tratado, los cuales deben velar por que los efectos de las disposiciones de la Convención no se vean mermadas por la aplicación de leyes contrarias a su objeto y fin. Es decir, a pesar del efecto relativo de las sentencias de la Corte IDH previsto en el artículo 68.1 de la CADH, y de la diversidad de ordenamientos jurídicos internos de los Estados partes, la jurisprudencia y la interpretación de la Corte debería ser tenida en cuenta y aplicada irrestrictamente, entre otros, por el legislador, por la Administración y por los tribunales nacionales, quedando escaso o nulo margen para disentir de ellas. Sobre los orígenes, evolución, fundamentos y críticas al control de convencionalidad, Contreras VASQuez 2015, 425-469.

13 Sentencia TC Rol No 616 (2007), c. 18.

14 Sentencia TC, Rol No 725 (2008), c. 12.

15 Sentencia TC, Rol No 2264 (2013), c. 33.
} 
investigación previa, su comunicación al presunto infractor y la oportunidad para que este pueda plantear defensas o alegaciones y rendir pruebas. Todo ello terminado, si procede, con una sanción fundada y solo por hechos que han sido objeto de cargos, susceptible de ser impugnada ante un tribunal ${ }^{16}$.

A su vez, la Corte IDH ha entendido que el artículo 8.1 CADH reconoce el llamado debido proceso legal, el cual hace referencia a las condiciones que deben cumplirse para asegurar la adecuada defensa de las personas cuyos derechos u obligaciones están bajo consideración judicial ${ }^{17}$. Aunque la Corte IDH en un principio restringió la aplicación del artículo 8.1 CADH al ámbito jurisdiccional, posteriormente ha consolidado una jurisprudencia sobre la exigibilidad de un debido proceso a los órganos de la Administración del Estado ${ }^{18}$. En esa línea, la Corte IDH ha señalado que a las autoridades administrativas no se les exige el cumplimiento de las garantías propias de un órgano jurisdiccional, sino la observancia de ciertas garantías destinadas a asegurar que la decisión no sea arbitraria ${ }^{19}$.

A mayor abundamiento, la Corte IDH ha defendido la vigencia del debido proceso en materia administrativa sancionadora sin acudir a la teoría del ius puniendi único. Para ello, la Corte IDH ha sostenido dos líneas argumentales. Por un lado, la Corte IDH ha afirmado que cuando los órganos de la Administración sancionan a una persona determinan sus derechos y obligaciones, por ende, deben respetar el debido proceso ya que ejercen funciones materialmente jurisdiccionales ${ }^{20}$. Por otro lado, la Corte IDH ha señalado que la discrecionalidad administrativa de imponer sanciones se ve limitada por los derechos humanos, entre ellos, las garantías judiciales del artículo 8 CADH. Por ello, la Administración no puede dictar actos sancionatorios sin otorgar a los infractores la garantía del debido proceso ${ }^{21}$.

16 Sentencia TC Rol No 2682 (2014), c. 12

17 Corte IDH OC-9/87 (1987), párrafo 28.

${ }^{18}$ A modo de ejemplo, Caso Claude Reyes y otros vs. Chile (2006). En esta sentencia la Corte IDH sostuvo que:

"118. El artículo 8.1 de la Convención no se aplica solamente a jueces y tribunales judiciales. Las garantías que establece esta norma deben ser observadas en los distintos procedimientos en que los órganos estatales adoptan decisiones sobre la determinación de los derechos de las personas, ya que el Estado también otorga a autoridades administrativas, colegiadas o unipersonales, la función de adoptar decisiones que determinan derechos.

119. De esta forma, las garantías contempladas en el artículo 8.1 de la Convención son también aplicables al supuesto en que alguna autoridad pública adopte decisiones que determinen tales derechos, tomando en cuenta que no le son exigibles aquellas propias de un órgano jurisdiccional, pero sí debe cumplir con aquellas garantías destinadas a asegurar que la decisión no sea arbitraria.

120. La Corte ha establecido que las decisiones que adopten los órganos internos que puedan afectar derechos humanos deben estar debidamente fundamentadas, pues de lo contrario serían decisiones arbitrarias".

19 Caso Claude Reyes y otros vs. Chile (2006), párrafo 119.

20 Caso del Tribunal Constitucional vs. Perú (2001), párrafo 71.

21 Caso Baena Ricardo y otros vs. Panamá (2001), párrafo 126. 
En síntesis, tanto el TC como la Corte IDH han sostenido la aplicabilidad del derecho al debido proceso en materia administrativa a partir de tres líneas argumentales: (i) el ejercicio de funciones materialmente jurisdiccionales por parte de órganos administrativos; (ii) la teoría del ius puniendi único; y (iii) la necesidad de límites al ejercicio de las potestades administrativas discrecionales. Todas estas líneas, cuál más, cuál menos, tienen un poder explicativo reducido. En cuanto a la primera, los órganos de la Administración no son órganos independientes e imparciales encargados de decidir en forma definitiva controversias entre particulares ${ }^{22}$ y las excepciones en que ello ocurre no hacen sino confirmar esta regla ${ }^{23}$. La actividad cotidiana de la Administración, aunque afecta favorable o desfavorablemente los derechos subjetivos 0 intereses legítimos de las personas, se identifica principalmente con la satisfacción de necesidades públicas en forma continua y permanente (artículo 3 Ley $\left.N^{\circ} 18.575\right)$. En relación con la segunda, es preciso señalar que, si bien es deseable desde el punto de vista del principio de igualdad una identidad de principios entre las sanciones penales y las sanciones administrativas, de su común origen no se sigue necesariamente la obligación de someterlas a un mismo régimen jurídico ${ }^{24}$. Además, la teoría del ius puniendi solo resultaría pertinente con ocasión de la actividad sancionadora de la Administración más no respecto de otras como la de ordenación, la empresarial, la de fomento o la de servicio público. Por último, aunque es necesario controlar el ejercicio de las potestades discrecionales, la Administración también está revestida de potestades regladas, por lo que, respecto de ellas se requeriría encontrar un fundamento o argumento diverso que avale la aplicabilidad del debido proceso.

22 GoRdilto 2013, 94. Así lo ha entendido también la jurisprudencia de la Corte Suprema a propósito del ejercicio de la potestad sancionadora por órganos administrativos. La Corte, aunque no ha cuestionado la imparcialidad de la Administración, ha precisado que el Consejo Nacional de Televisión, en tanto substanciador del procedimiento sancionador regulado en la Ley $N^{\circ} 18.168$, es un órgano administrativo que no tiene el carácter de tribunal de la República. Por ende, las decisiones del Consejo adoptan la forma de resoluciones (no de sentencias definitivas), y son reclamables ante la Corte de Apelaciones de Santiago. Megamedia S.A. (2021).

23 Excepcionalmente algunos órganos administrativos ejercen, según el caso, funciones cuasi jurisdiccionales o jurisdiccionales, en la medida que dirimen controversias entre particulares o entre particulares y la Administración. Ejemplo de lo primero serían las resoluciones del Director del Instituto Nacional de Propiedad Industrial que resuelven las oposiciones que cualquier interesado formule a las solicitudes de marcas, patentes de invención, modelos de utilidad, dibujo y diseño industrial, esquemas de trazado o topografía de circuitos integrados e indicaciones geográficas y denominaciones de origen (artículos 4 y ss. DFL N ${ }^{\circ} 3 / 2006$ ). Con todo, esta atribución del Director puede calificarse de actividad cuasi jurisdiccional en la medida que no resuelve la controversia en forma definitiva, sino que sus resoluciones son apelables ante el Tribunal de Propiedad Industrial. Ejemplo de lo segundo, esto es, de auténtico ejercicio jurisdiccional, sería el juzgamiento de las cuentas de las personas que tengan o hubieren tenido a su cargo bienes o fondos públicos (artículo $98 \mathrm{CPR}$ ), actividad desarrollada en primera instancia por el Subcontralor y en segunda instancia por el Tribunal de Cuentas (artículos 85 y ss. Ley $N^{\circ} 10.336$ ). Sobre este punto, FerRAda Bórouez 2011, 136-142.

24 Letelier Wartenberg 2017, 633. 
No obstante, a pesar de las limitaciones de las líneas argumentales precedentemente expuestas, es posible identificar otros fundamentos de la aplicabilidad del debido proceso en sede administrativa. Por un lado, en sintonía con el derecho estadounidense ${ }^{25}$, el debido proceso administrativo o sustantivo constituiría un límite a la arbitrariedad en el marco de nuestro Estado democrático de Derecho ${ }^{26}$. Por otro lado, este derecho operaría como un mecanismo de control del cumplimiento del fin de la Administración: la promoción del bien común (artículo 1 CPR y artículo 3 Ley $N^{\circ} 18.575$ ). En ese sentido, a la Administración se le exige respetar garantías procedimentales a fin de adoptar decisiones razonables ${ }^{27}$.

Las garantías procedimentales básicas que debe respetar la Administración forman parte de los principios del procedimiento administrativo mencionados en el artículo 4 de la Ley $\mathrm{N}^{0} 19.880^{28}$, y son fundamentalmente: la contradictoriedad, la publicidad y la celeridad del procedimiento y la impugnación del acto administrativo. A ellas debe añadirse una garantía sustantiva: la motivación del acto administrativo. La conjunción de estas garantías procedimentales y de esta garantía sustantiva, cuyo fin último es obtener la razonabilidad del acto administrativo, debería denominarse debido procedimiento sustantivo en el derecho chileno ${ }^{29}$.

\section{Lineamientos generales sobre el debido procedimiento administrativo sancionador}

Sin perjuicio de que el artículo 4 de la Ley $N^{\circ} 19.880$ garantiza un debido procedimiento sustantivo, surge el interrogante acerca de si, en los procedimientos administrativos sancionadores (aquellos que pueden culminar en la imposición de multas, u otro tipo de sanciones no privativas de libertad, a quienes hayan cometido una infracción administrativa), la Administración debería respetar adicionalmente otras garantías como la comunicación de la acusación. La respuesta es afirmativa, no solo a partir de la teoría del ius puniendi único como frecuentemente se sostiene, sino también y principalmente en consideración de las características del Estado democrático de derecho chileno.

Tradicionalmente se ha esgrimido como fundamento para la concesión de mayores garantías a los particulares en un procedimiento sancionador la tesis del ius puniendi único, según la cual las penas y las sanciones administrativas son ontológicamente idénticas y deben ser sometidas a similar estatuto de garantías. Entre los partidarios de la tesis del ius puniendi es posible

\footnotetext{
25 Williams 2010, 417-419.

26 Bordalí Salamanca 2016, 201.

27 Boutaud Scheuermann 2018, 28.

28 "Principios del procedimiento. El procedimiento administrativo estará sometido a los principios de escrituración, gratuidad, celeridad, conclusivo, economía procedimental, contradictoriedad, imparcialidad, abstención, no formalización, inexcusabilidad, impugnabilidad, transparencia y publicidad".

En un sentido similar, Sentencia TC Rol N 771 (2007), c. 16.

29 Boutaud Scheuermann 2018, 76.
} 
distinguir dos variantes: una que propugna la aplicación total de las garantías penales en el derecho administrativo sancionador y otra, la mayoritaria, que sostiene la aplicación matizada de estas. Ambas versiones han sido objeto de diversas críticas por parte de la doctrina nacional en los últimos años ${ }^{30}$. Por ejemplo, Letelier Wartenberg ha rechazado esta teoría. En esa línea, este autor ha expresado que la tesis de la identidad entre las penas y las sanciones administrativas, y la aplicación de garantías penales a estas últimas, encubre una discusión axiológica, pues no resulta efectivo que no existan regulaciones legales y administrativas sobre la materia. A su juicio, quienes defienden esta tesis fabrican una laguna por considerar políticamente insuficientes los contenidos de dichas regulaciones ${ }^{31}$. Además, esta tesis no serviría para explicar las diferencias regulativas existentes entre las sanciones administrativas y las penas, por ejemplo, en cuanto al procedimiento y los órganos que las aplican, las que, desde esa perspectiva, resultarían contrarias a su común origen ${ }^{32}$.

Al respecto parece claro que el traspaso automático de todas las garantías del debido proceso penal a los procedimientos administrativos sancionadores no resulta conveniente. La aplicación de todas las garantías procedimentales penales, previstas, por ejemplo, en el Código Procesal Penal ${ }^{33}$, pugna con la eficiencia y la eficacia en el ejercicio de la potestad administrativa sancionadora. Asimismo, la aplicación de estas garantías, en algunos casos, contraviene o, en una primera aproximación, no se encuentra en sintonía con las regulaciones administrativas ${ }^{34}$.

30 Entre otros, Ferrada Bórouez 2014, 242-243; Letelier Wartenberg 2017, 636-638; Van Weezel De LA CRUZ 2017, 997-1043.

31 Letelier WartenBerg 2017, 628-632.

32 Ibíd., 632-634.

${ }_{33}$ Conviene aclarar que la doctrina mayoritaria, aunque conteste en la vigencia de algunos principios penales como la presunción de inocencia, no ha afirmado abiertamente la aplicabilidad de todas las garantías del Código Procesal Penal en los procedimientos administrativos sancionadores. Entre otros, Vergara Blanco 2004, 144-145, Bermúdez Soto 2014, 351; Cordero Quinzacara $2014,433-434$. Solo excepcionalmente algunos autores, y con diverso alcance, han propuesto la aplicación de las reglas y de los principios del Código Procesal Penal en el derecho administrativo sancionador. Enteiche Rosales 2014, 298-300, RomÁn Cordero 2014, 200.

34 Ibíd., 622-671. Por ejemplo, ello ocurriría con el derecho a la no autoincriminación. Las leyes especiales sobre infracciones y sanciones administrativas no se refieren al derecho a la no autoincriminación. Al contrario, de estas leyes sectoriales pareciera desprenderse un deber de colaboración de los investigados y de los testigos quienes, habiendo sido citados a declarar, están obligados a comparecer bajo apercibimiento de arresto (por ejemplo, en materia eléctrica o en el ámbito financiero). Incluso, las personas que presten declaraciones falsas ante la Administración pueden ser sancionadas penalmente (artículo 35 inciso final Decreto Ley 3.538). En este contexto, una estricta aplicación de la teoría del ius puniendi único tornaría en inconstitucionales numerosas infracciones administrativas consistentes en proporcionar a los órganos administrativos, por ejemplo, una Superintendencia, información relevante para el ejercicio de su potestad fiscalizadora (artículo 76 letra b) Ley $N^{\circ}$ 20.529).

Sin embargo, al igual que ocurre con la presunción de inocencia, a partir de argumentos como el analógico, el pro homine, o la interpretación evolutiva de los derechos humanos, es posible sostener una aplicación matizada del derecho a la autoincriminación en el derecho administrativo sancionador. Bajo esta interpretación, no serían inconstitucionales los deberes de colaboración de los administrados en los procedimientos sancionadores, pues las pruebas obtenidas a partir 
No ocurre lo mismo con la aplicación parcial o matizada de las garantías procedimentales penales en el derecho administrativo sancionador pues la eficiencia y la eficacia no son los únicos factores a considerar en un Estado democrático de derecho. Al respecto debe considerarse que la Administración puede afectar, incluso de manera más grave que el derecho penal, algunos derechos fundamentales e intereses legítimos de las personas, tales como la libertad de enseñanza, la libertad de asociación, la libertad de empresa, el derecho de propiedad y, subsidiariamente, el derecho a la libertad personal ante el no pago de una multa (sustitución y apremio). Es decir, si bien la mayoría de las sanciones administrativas son patrimoniales, no por ello resultan leves para sus destinatarios, pues implican una afectación de derechos fundamentales asegurados por la propia Constitución. Así, en un Estado democrático de derecho, aunque es legítima la potestad sancionadora, no resulta admisible la primacía a todo evento de la eficiencia y la eficacia administrativa por sobre los derechos individuales de los ciudadanos, cuanto más si se considera el riesgo de arbitrariedad y abuso en el ejercicio de las potestades administrativas ${ }^{35}$. Por ende, en un Estado democrático de derecho, los afectados por la decisión de un procedimiento sancionador deben tener derecho a ser informados adecuadamente sobre los cargos formulados, a participar activamente en él y a poder recurrir en contra de la resolución sancionadora.

Si bien la tesis de los matices adolece de un grado de indeterminación que posibilita que a la Administración se le exija respetar las garantías penales prácticamente en los mismos términos que en los procesos penales ${ }^{36}$, también es posible superar esta dificultad. Así, Gómez Tomillo ${ }^{37}$ ha distingui-

\footnotetext{
de ellos serían de resultado incierto, no de carácter directamente incriminatorio. Por esta razón, tampoco menoscaban el derecho a la presunción de inocencia en sede administrativa, ya que la carga de la prueba seguirá recayendo en la Administración, la que podrá hacer uso de las declaraciones o documentos proporcionados por el infractor como uno de los diversos medios idóneos para tal fin. En similar sentido, Sentencia TC España Nº 197 (1995).

35 Gómez Tomillo 2020, 10.

36 Por ejemplo, Cordero Quinzacara 2014, 421-422, sostiene que la aplicación del principio de culpabilidad en el derecho administrativo sancionador se traduce en: (i) la proscripción de la responsabilidad objetiva; (ii) la determinación de la sanción de acuerdo a la magnitud de la culpabilidad; (iii) el carácter personal de la responsabilidad sancionadora administrativa; y (iv) la contrariedad con este principio de aquellas infracciones administrativas calificadas por el resultado. Como se aprecia, el planteamiento de este autor no permite identificar cuál o cuáles serían los matices en cuanto a la aplicación del principio de culpabilidad en sede administrativa. En similar sentido, Vergara Blanco 2004, 143.

37 Gómez Tomillo 2020, 24-31. Si bien esta propuesta se ha formulado respecto de un ordenamiento jurídico diverso como es el español, en el que a diferencia de nuestro país hay un expreso reconocimiento constitucional de la potestad sancionadora, la situación a nivel de la jurisprudencia constitucional es la misma, pues el Tribunal Constitucional español ha sostenido la aplicación matizada de los principios penales en el derecho administrativo sancionador. Siendo así, resulta relevante para el derecho chileno la propuesta de Gómez en orden a que es posible precisar el contenido de los matices en la aplicación de los principios penales en el derecho administrativo sancionador.
} 
do entre principios procesales matizables ${ }^{38}$ y no matizables ${ }^{39}$, señalando que solo los primeros operarían de modo diferente, pues atenderían a las características intrínsecas del procedimiento administrativo sancionador (es un órgano de la Administración el que impone la sanción, no un tribunal de justicia), mientras que los segundos serían consustanciales al Estado democrático de derecho.

Sin perjuicio de que se pudiera disentir en algunos aspectos de la sistematización de Gómez Tomillo, es de rescatar su propuesta en cuanto reduce las indeterminaciones de los "matices" a que se somete la aplicación de los principios penales en el derecho administrativo sancionador. Asimismo, acertadamente, este autor ha situado la discusión sobre las garantías del derecho administrativo sancionador en el marco de un Estado democrático de Derecho (artículos 4, 6 y 7 CPR). En ese marco, se favorece la participación de los afectados por una decisión pública (en este caso los destinatarios de un procedimiento sancionador) y se contemplan mecanismos de control de la actividad administrativa. Por estas razones, las leyes especiales sobre infracciones y sanciones administrativas han reforzado los derechos del administrado en los procedimientos administrativos sancionadores haciendo aplicables ciertas garantías procedimentales penales, tales como: (i) el derecho a la comunicación previa y precisa de los cargos formulados ${ }^{40}$; (ii) el derecho a conocer, solicitar y participar de las diligencias probatorias ${ }^{41}$; y (iii) el derecho a impugnar la resolución sancionatoria ante un juez o tribunal ${ }^{42}$. Estas garantías son una

\footnotetext{
${ }_{38}$ (i) la garantía de independencia (jerarquía) e imparcialidad (objetividad); (ii) el derecho a un juez ordinario predeterminado por la ley; (iii) el derecho a la defensa letrada; el derecho a intérprete y traductor; (iv) la separación (orgánica) entre la instrucción y el enjuiciamiento (se trataría de una separación funcional); (v) el derecho a un proceso público; (vi) el derecho a ser oído; y (vii) el derecho a la doble instancia.

39 (i) el derecho a la presunción de inocencia; (ii) el derecho a guardar silencio, a no declararse culpable y a no declarar contra sí mismo; (iii) el derecho a la confidencialidad de las comunicaciones entre abogado y cliente; (iv) el derecho a ser informado de la acusación; (v) el principio acusatorio (correlación entre la acusación y la resolución sancionadora); (vi) el derecho a utilizar los medios de prueba pertinentes para la defensa; (vii) la prohibición de dilaciones indebidas; y (viii) el principio de non bis in ídem procedimental.

40 Por ejemplo, en materia ambiental se exige que la formulación de cargos realice "una descripción clara y precisa de los hechos que se estimen constitutivos de infracción y la fecha de su verificación, la norma, medidas o condiciones eventualmente infringidas y la disposición que establece la infracción, y la sanción asignada" (artículo 49 inciso segundo de la Ley $N^{\circ} 20.417$ ).

41 Por ejemplo, el artículo 49 inciso final del Decreto Ley № 3.538 establece que: "La práctica de las diligencias probatorias que se decreten en el procedimiento sancionatorio deberá notificarse a todos los interesados que participen en dicho procedimiento".

42 Las resoluciones sancionadoras son impugnables tanto en sede administrativa como judicial. Por ejemplo, de acuerdo al artículo 18 A de la Ley $N^{\circ} 18.410$, las sanciones aplicadas por la Superintendencia de Electricidad y Combustibles son impugnables administrativamente a través del recurso de reposición y del recurso jerárquico si procediere. Luego, estas resoluciones sancionatorias son reclamables ante la Corte de Apelaciones del domicilio del afectado (artículo 19 Ley $N^{\circ} 18.410$ ).

Un asunto distinto es si el control judicial de la aplicación de sanciones administrativas debe ser amplio o restrictivo. Sobre este punto, DUCE JULIO 2018, 93-97.
} 
base esencial de los procedimientos administrativos sancionadores ${ }^{43}$ y constituyen una concreción de los principios de contradictoriedad y de impugnabilidad de los actos administrativos.

Como se aprecia, nuestro legislador ha asegurado un debido procedimiento sancionador, otorgado mayores garantías a los particulares, no solo como una derivación de la tesis del ius puniendi, sino principalmente como estándares de protección, participación y control de las decisiones públicas en el marco de un Estado democrático de derecho. En ese contexto, se analizará en la siguiente sección si la presunción de inocencia forma parte o no del debido procedimiento sancionador.

\section{La presunción de inocencia en los procedimientos administrativos sancionadores}

La presente sección tiene por objetivo analizar si acaso forma parte del debido procedimiento administrativo sancionador el derecho a la presunción de inocencia. Con dicho fin, se revisan los orígenes y principales manifestaciones penales de esta garantía, su traslación hacia los procedimientos sancionadores realizada por la doctrina y la jurisprudencia, y se propone su aplicabilidad con matices en sede administrativa.

\section{Orígenes y principales significados de la presunción de inocencia}

La presunción de inocencia es un derecho humano o fundamental que surgió hacia fines del siglo XVIII como reacción al proceso penal del Antiguo Régimen $^{44}$. El proceso penal del Antiguo Régimen era inquisitivo y sus principales características eran: (i) el secreto de sus actuaciones; (ii) la reunión en el juez de las labores de investigación, acusación y decisión; (iii) la vigencia de un sistema de prueba tasada; y (iv) la desigualdad de las partes en perjuicio del imputado ${ }^{45}$. En este proceso penal no regía una presunción de inocencia sino una presunción de culpabilidad. El imputado era un objeto de prueba ya que estaba obligado a colaborar con el esclarecimiento de los hechos. La declaración de culpabilidad del imputado se obtenía a través de distintos medios tales como la indagatoria, la confesión con cargos y el tormento ${ }^{46}$.

Frente a esta situación, a partir de la Revolución Francesa y el movimiento codificador, comienza progresivamente a humanizarse el proceso penal, reconociendo ciertos límites que el poder punitivo estatal debe respetar, en-

\footnotetext{
43 En un sentido similar, el Tribunal Constitucional ha sostenido que la omisión de una regulación legal sobre el procedimiento administrativo sancionador se salvaría si la respectiva autoridad instruye una investigación que cumpla las exigencias básicas de un debido proceso: la formulación de cargos, su notificación al inculpado y una oportunidad efectiva para que este pueda ejercer su derecho a defensa, por ejemplo, allegando y produciendo pruebas. Sentencia TC Rol No 2682 (2014).

44 Fernández López 2004, 171.

45 Ibíd., 171.

46 lbíd., 172-175.
} 
tre ellos, la presunción de inocencia ${ }^{47}$. El proceso penal transita gradualmente desde un sistema inquisitivo a un sistema acusatorio en que el imputado es un sujeto de derechos y puede participar en el proceso en igualdad de condiciones con la parte acusadora ${ }^{48}$.

Actualmente, la presunción de inocencia se encuentra consagrada en diversas Constituciones y en tratados internacionales de derechos humanos ${ }^{49}$. En el caso chileno, ante la ausencia de una referencia expresa a este derecho en nuestra Constitución, la presunción de inocencia podría considerarse un derecho implícito derivado del artículo 1 CPR (dignidad humana) o del artículo $19 \mathrm{~N}^{\circ} 3$ CPR inciso sexto (debido proceso) o séptimo (prohibición de las presunciones de derecho en responsabilidad penal) ${ }^{50}$. Sin perjuicio de ello, la presunción de inocencia se encuentra regulada explícitamente en el artículo $8.2 \mathrm{CADH}$, tratado internacional sobre derechos humanos ratificado y actualmente vigente en nuestro país, que, en virtud de lo prescrito en el artículo 5 inciso segundo CPR, opera como un límite al ejercicio de la soberanía y debe ser respetado y promovido por el Estado chileno. Además, a nivel legal, la presunción de inocencia es mencionada en el artículo 4 del Código Procesal Penal ${ }^{51}$. De esta pluralidad de fuentes es perfectamente posible concluir que la presunción de inocencia es un derecho humano, que, pese a su universalidad, también ha sido regulado implícita y explícitamente en Chile.

En un Estado de Derecho, la presunción de inocencia protege la libertad de los individuos ${ }^{52}$ imponiendo diversas obligaciones al juez o tribunal, a los intervinientes del proceso penal y a los conciudadanos ${ }^{53}$. Esta diversidad de obligaciones es ilustrativa de la ambigüedad de la expresión presunción de inocencia, ya que al hacer referencia a ella se puede estar hablando de diferentes manifestaciones o facetas de la misma. Los principales significados o manifestaciones de la presunción de inocencia, como derecho subjetivo del imputado, son tres ${ }^{54}$ :

\footnotetext{
47 La Declaración de los Derechos del Hombre y del Ciudadano de 1789 reconoció la presunción de inocencia en su artículo 9 bajo los siguientes términos: "Puesto que cualquier hombre se considera inocente hasta no ser declarado culpable, si se juzga indispensable detenerlo, cualquier rigor que no sea necesario para apoderarse de su persona debe ser severamente reprimido por la Ley".

48 Fernández López 2004, 176-182.

49 Por ejemplo, el artículo 6.2 del Convenio Europeo de Derechos Humanos establece que: "Toda persona acusada de una infracción se presume inocente hasta que su culpabilidad haya sido legalmente declarada".

50 Sentencia TC Rol No 1518 (2010), c. 33.

51 "Ninguna persona será considerada culpable ni tratada como tal en tanto no fuere condenada por una sentencia firme". En estricto rigor, como afirma Valenzuela Saldías, el artículo 4 del Código Procesal Penal, no obstante estar ubicado dentro de los principios del proceso penal, regula la presunción de inocencia como regla de trato. VALENZUELA SALDías 2011, 66.

52 Ho afirma que la presunción de inocencia protege a los individuos de una injusta y arbitraria interferencia del Estado en la persecución y juzgamiento de delitos. De este modo, la presunción de inocencia sería un mecanismo de control de la arbitrariedad estatal. Ho 2012, 277-279.

53 DufF 2013, 170-192.

54 Ferrer Beltran 2010, 5-23; Fernández López 2004, 209-249. No se hará referencia a la presunción de inocencia como principio del proceso penal que obligaría al legislador y a los jueces a
} 
a) La presunción de inocencia como regla de trato. De conformidad con esta regla de trato, el imputado tiene derecho a ser considerado o tratado como inocente mientras no haya sido condenado por una sentencia firme. La presunción de inocencia como regla de trato prohíbe, por regla general, la anticipación de las consecuencias propias de la sanción penal al imputado, sobre todo su privación de libertad ${ }^{55}$. Por ello, las medidas cautelares personales, entre ellas, la prisión preventiva, deberían tener un alcance restringido en el proceso penal ${ }^{56}$, más allá del cual son calificadas como una pena anticipada vulneradora de la presunción de inocencia como regla de trato ${ }^{57}$.

En su dimensión extraprocesal ${ }^{58}$, la presunción de inocencia como regla de trato impone una obligación (de abstención) a todas las autoridades estatales (no solo los jueces) y a los privados ${ }^{59}$. Las autoridades estatales y los medios de comunicación, al informar sobre un proceso penal en curso, no deben emitir declaraciones que propicien un prejuicio social de responsabilidad del imputado en los hechos, mientras no haya sentencia firme que así lo establezca ${ }^{60}$.

b) La presunción de inocencia como regla sobre la distribución de la carga de la prueba formal o subjetiva ${ }^{61}$. Esta dimensión de la presunción de

respetar los derechos del imputado. Como señala Ferrer Beltrán, este significado de la presunción de inocencia se reduce a la aplicación de los derechos subjetivos del imputado y por tanto no es una faceta independiente de los mismos. Ferrer Beltrán 2010, 6-8.

55 Horvitz LenNon y López MASLE 2002 tomo I, 82-84.

56 Nogueira Alcala 2005, 223. En ese sentido el artículo 122 del Código Procesal Penal establece que: "Las medidas cautelares personales solo serán impuestas cuando fueren absolutamente indispensables para asegurar la realización de los fines del procedimiento y solo durarán mientras subsistiere la necesidad de su aplicación".

57 Horvitz Lennon y López Masle 2002 tomo I, 84-86. En el mismo sentido, Caso Norín Catrimán y otros (Dirigentes, miembros y activista del Pueblo Indígena Mapuche) vs. Chile (2014), párrafo 361, afirma que la prisión preventiva "no puede constituirse como una pena anticipada que contravenga el principio de presunción de inocencia que protege al imputado".

58 FerRer Beltrán 2010, 3-5.

59 Duff 2013, 180-182, por su parte, habla de una presunción de inocencia cívica que refleja la confianza que debemos tenernos entre conciudadanos. La presunción de inocencia cívica protege a los ciudadanos de ser tratados por otros ciudadanos como culpables de delitos futuros y de delitos respecto de los cuales han cumplido la pena.

60 Por ejemplo, la Corte IDH ha manifestado que: "El derecho a la presunción de inocencia exige que el Estado no condene informalmente a una persona o emita juicio ante la sociedad, contribuyendo así a formar una opinión pública, mientras no se acredite su responsabilidad penal conforme a la ley. Por ello, ese derecho puede ser violado tanto por los jueces a cargo del proceso, como por otras autoridades públicas, por lo cual estas deben ser discretas y prudentes al realizar declaraciones públicas sobre un proceso penal, antes de que la persona haya sido juzgada y condenada". Caso Acosta y otros vs. Nicaragua (2017), párrafo 190.

${ }^{61}$ En este punto no se ha seguido completamente la clasificación de Ferrer Beltrán y Fernández López pues solo se rescatará un aspecto de la presunción de inocencia como regla probatoria que estos autores mencionan: el relativo a la carga de la prueba (formal o subjetiva). Como señala FerReR BeLtRÁ 2010, 12-16, la presunción de inocencia como regla probatoria impone exigencias que forman parte de la presunción de inocencia como regla de juicio (actividad probatoria de cargo suficiente) o de otros derechos fundamentales (exclusión de la prueba ilícita y práctica de la prueba en un contradictorio). En este contexto, solo queda entender la presunción de ino- 
inocencia tiene como destinatarios a los intervinientes del proceso penal, principalmente a la Fiscalía, al querellante y al imputado. De acuerdo con esta regla sobre la carga de la prueba, la iniciativa probatoria corresponde a la acusación (al Ministerio Público y al querellante si lo hubiere) quien debe aportar al proceso pruebas que acrediten los hechos, la participación del imputado y las circunstancias agravantes de responsabilidad ${ }^{62}$. Sobre el imputado no recae la carga de demostrar su inocencia ${ }^{63}$, aunque puede plantear hipótesis exculpatorias y presentar pruebas de descargo, recayendo sobre la acusación la carga de aportar contrapruebas ${ }^{64}$. La presunción de inocencia como regla sobre la carga de la prueba impide la inversión de la carga de la prueba en perjuicio del imputado ${ }^{65}$.

c) La presunción de inocencia como regla sobre la carga de la prueba material u objetiva, regla de juicio o regla sobre el estándar de prueba. Esta dimensión de la presunción de inocencia resulta relevante al momento de valorar la prueba y obliga al juez a absolver al acusado en caso de duda sobre los hechos constitutivos de la pretensión penal, pues a la acusación correspondía probarlos ${ }^{66}$. Para ser operativa, la presunción de inocencia como regla de juicio requiere de un estándar de prueba cuya aplicación sea intersubjetivamente controlable ${ }^{67}$. De esta manera se sabrá frente a qué resultado probatorio el imputado tendrá derecho a una sentencia absolutoria. En Chile el estándar de prueba penal requiere del tribunal un grado de convicción más allá de toda duda razonable (artículo 340 inciso primero del Código Procesal

cencia como una regla sobre la distribución de la carga de la prueba, lo que de todos modos dicho autor cuestiona en razón del peligro de expansión de la presunción de inocencia a ámbitos no sancionadores.

62 Fernández López 2004, 373.

63 Nogueira Alcalá 2005, 227. De todos modos, en la doctrina y jurisprudencia se discute la distribución de la carga de la prueba y el estándar probatorio sobre las defensas que pudiera plantear el imputado (atipicidad de la conducta, causales de justificación, causales de exculpación, atenuantes, prescripción, cosa juzgada, etc.). Sobre este punto, FernÁndez López 2004, 94-101; Cuerda Riezu 2014, 1-14.

64 En palabras de la Corte IDH: "[...] la carga de la prueba se sustenta en el órgano del Estado, quien tiene el deber de probar la hipótesis de la acusación y la responsabilidad penal, por lo que no existe la obligación del acusado de acreditar su inocencia ni de aportar pruebas de descargo. Es decir, la posibilidad de aportar contraprueba es un derecho de la defensa para invalidar la hipótesis acusatoria, contradiciéndola mediante contrapruebas o pruebas de descargo compatibles con hipótesis alternativas (contra-hipótesis), que a su vez la acusación tiene la carga de invalidar". Caso Zegarra Marín vs. Perú (2017), párrafo 140. Sobre este punto, Fernández López sostiene que el ejercicio del derecho del imputado a presentar prueba de descargo se convierte en una carga cuando la acusación ha aportado pruebas incriminatorias más allá de toda duda razonable. FERNÁNDEZ LÓPEZ 2004, 464.

65 Nogueira Alcalá 2005, 237; Fernández López 2004, 440.

66 Fernández López 2004, 462.

67 En palabras de Ferrer Beltrán, "el derecho a la presunción de inocencia presupone la vigencia de un estándar de prueba pero no implica estándar de prueba alguno". Ferrer Beltrán 2010, 16-20. 
Penal $\left.{ }^{68}\right)$, de manera que, en caso de duda razonable, por aplicación de esta regla de juicio, el juez o tribunal debe absolver al imputado.

En síntesis, los principales significados de la presunción de inocencia en el proceso penal dan cuenta de obligaciones relativas al tratamiento que debe recibir el imputado, a la iniciativa probatoria y al grado de suficiencia que debe tener la prueba de cargo. En el apartado siguiente se expondrá cuál o cuáles de estas dimensiones de la presunción de inocencia han sido objeto de interés por parte de nuestra doctrina y la jurisprudencia del TC en el ámbito del derecho administrativo sancionador.

\section{La presunción de inocencia en la doctrina y en la jurisprudencia del Tribunal Constitucional}

La presunción de inocencia, en general, no se encuentra contemplada en las leyes sectoriales que regulan la potestad sancionadora de la Administración ${ }^{69}$. Pese a ello, la doctrina y el TC, con base en la teoría del ius puniendi, han afirmado la procedencia de sus manifestaciones en el procedimiento administrativo sancionador. De este modo, asumida por la doctrina y la jurisprudencia la identidad ontológica entre las infracciones y sanciones administrativas y los delitos y las penas, se deriva la aplicación matizada de algunas garantías penales en el derecho administrativo sancionador, entre ellas, la presunción de inocencia.

En esa línea, la doctrina administrativa mayoritaria ha afirmado la aplicación de los límites al ius puniendi en los procedimientos administrativos sancionadores, entre ellos, la presunción de inocencia, sin precisar a cuál

\footnotetext{
68 "Nadie podrá ser condenado por delito sino cuando el tribunal que lo juzgare adquiriere, más allá de toda duda razonable, la convicción de que realmente se hubiere cometido el hecho punible objeto de la acusación y que en él hubiere correspondido al acusado una participación culpable y penada por la ley".

69 Excepcionalmente, la presunción de inocencia parece encontrarse prevista como una regla de trato hacia el presunto infractor en regulaciones más recientes, por ejemplo, en la Ley № 20.417 (artículos 47, 49 y 50) y en el Decreto Ley N 3.538 (párrafo del título IV y artículo 82). Ahora bien, del hecho que las demás leyes sectoriales no se refieran expresamente a la presunción de inocencia, y en cambio establezcan presunciones legales de responsabilidad, no es posible concluir que tajantemente rechacen la procedencia de este derecho, solo se desprende que guardan silencio al respecto. A mayor abundamiento, si el legislador hubiera querido reducir las garantías del procedimiento sancionador y descartar indiscutiblemente la procedencia de la presunción de inocencia lo hubiera manifestado explícitamente en las normativas sectoriales administrativas, situación que no ha ocurrido. Por lo demás, como se expresará más adelante, las presunciones legales de responsabilidad admiten una interpretación conforme con la presunción de inocencia.

A nivel comparado, el artículo 53.2.b) de la Ley española del Procedimiento Administrativo Común de las Administraciones Públicas establece que, en el caso de los procedimientos administrativos sancionadores, los presuntos responsables tendrán derecho a "la presunción de no existencia de responsabilidad administrativa mientras no se demuestre lo contrario". En un sentido similar, el artículo 230 número 9 de la Ley peruana del Procedimiento Administrativo General menciona, dentro de los principios de la potestad sancionadora, a la presunción de licitud en virtud de la cual: "Las entidades deben presumir que los administrados han actuado apegados a sus deberes mientras no cuenten con evidencia en contrario".
} 
o cuáles de los significados de la presunción de inocencia se refieren ${ }^{70}$. No obstante, existen excepciones. Vergara Blanco señala que la presunción de inocencia impone a la Administración la carga de aportar pruebas que acrediten la responsabilidad del destinatario de la sanción ${ }^{71}$. Cordero Quinzacara es partidario de la vigencia de la presunción de inocencia como regla de trato y como regla sobre la carga de la prueba en los procedimientos administrativos sancionadores. Por ello, este autor cuestiona las presunciones de responsabilidad en el derecho administrativo sancionador ${ }^{72}$. Por último, Hunter Ampuero defiende la aplicación de la presunción de inocencia como regla sobre la carga de la prueba formal y material. En virtud de esta regla, la carga de producir prueba válida y contradictoria, que acredite la responsabilidad del particular, le corresponde siempre a la Administración, siendo ella la que soportará las consecuencias de la falta o insuficiencia de prueba ${ }^{73}$.

En cuanto al TC, su jurisprudencia sobre la presunción de inocencia en el derecho administrativo sancionador no es uniforme. Por un lado, el TC ha afirmado la vigencia de la presunción de inocencia como regla de trato en materia de sanciones administrativas, mientras la decisión administrativa no se encuentre ejecutoriada ${ }^{74}$. Por otro lado, el TC ha sostenido que "la presunción de inocencia no resulta adecuada a la esfera del derecho administrativo sancionador, puesto que dicha categoría conceptual, se relaciona más bien con el campo penal y procesal penal ${ }^{75 "}$. Asimismo, el TC ha reconocido la vigencia de la presunción de inocencia como regla sobre la carga de la prueba en los procedimientos administrativos. Ello ha ocurrido respecto de ciertas presunciones legales sobre la comisión de la infracción a partir de la denuncia formulada por un funcionario de la Administración, a quien se le otorga la calidad de ministro de fe. El TC, en algunos $\operatorname{casos}^{76}$, las ha calificado como inconstitucionales por ser constitutivas de presunciones de responsabilidad que asignan al administrado la carga de probar su inocencia y le impiden probar la inexistencia de la infracción a partir de otros antecedentes o circunstancias ${ }^{77}$. Incluso, el TC ha señalado que las presunciones de culpabilidad pueden derivarse no solo de un precepto determinado sino también de un conjunto de disposiciones que restrinjan el derecho del administrado de presentar eficazmente alegaciones y pruebas en contrario ${ }^{78}$.

\footnotetext{
70 RomÁn CORDERO 2014, 202. En la doctrina no administrativista, algunos autores afirman la aplicabilidad de la presunción de inocencia en materia de sanciones administrativas, sin especificar su contenido. Ferrer Beltrán 2010, 4; Nogueira Alcalá 2005, 238.

71 Vergara Blanco 2004, 144-145.

72 Cordero Quinzacara 2014, 434.

73 Hunter Ampuero 2015, 660.

74 Sentencia TC Rol No 1518 (2010).

75 Sentencia TC Rol No 2722 (2015).

76 Sentencia TC Rol Nº 8696 (2020), considerando 16; Sentencia TC Rol Nº 6437 (2019), considerando 14.

77 En contra, Sentencia TC Rol N 4446 (2019); Sentencia TC Rol Nº 7318 (2020).

78 Sentencia TC Rol No 1518 (2020), considerando 35.
} 
En síntesis, en general, la doctrina y la jurisprudencia del TC no han cuestionado, sino que han asumido la aplicación de la presunción de inocencia en el derecho administrativo sancionador. Para ello, han esgrimido como singular y gran argumento la teoría del ius puniendi único, pasando por alto que existen otros argumentos que respaldarían esta conclusión, tales como el sistemático, el principio pro persona y el carácter evolutivo de los derechos humanos. Asimismo, ni la doctrina ni la jurisprudencia han delineado o especificado los matices que tendría la aplicación de la presunción de inocencia en los procedimientos sancionadores. Por estas razones, en las secciones siguientes se analizarán algunos cuestionamientos a la aplicación de la presunción de inocencia, en los mismos términos que en el proceso penal, en el derecho administrativo, para posteriormente defender su vigencia con matices en esta área del derecho ${ }^{79}$.

\section{Objeciones a la aplicación no matizada de la presunción de inocencia en los procedimientos administrativos sancionadores}

La aplicación de la presunción de inocencia en los procedimientos administrativos sancionadores, en los mismos términos que en el proceso penal, no resulta infundada. Argumentos como (i) el principio pro persona (artículo 29 CADH), (ii) el carácter evolutivo de los derechos humanos, (iii) la teoría del ius puniendi único o (iv) simplemente las similitudes entre las sanciones penales y las sanciones administrativas respaldarían una identidad en cuanto a las garantías procedimentales aplicables, entre ellas, la presunción de inocencia ${ }^{80}$. No obstante, estas razones pueden ser contrarrestadas si se consideran otros factores en esta discusión.

En primer lugar, en cuanto a los argumentos relativos a la interpretación de los derechos humanos (i y ii), podría argüirse que resulta conveniente establecer un límite al carácter evolutivo o expansivo de la presunción de inocencia en tanto derecho humano. En el proceso penal rige una presunción de inocencia en razón del riesgo de afectación directa de la libertad personal del imputado ${ }^{81}$, riesgo que, salvo excepciones como las sanciones migratorias, no se encuentra presente en materia administrativa, pues las sanciones recaen sobre el patrimonio del infractor. Además, el proceso penal tiene un efecto estigmatizador respecto del imputado ${ }^{82}$, afectación del derecho al honor del infractor que prácticamente no se produce en sede administrativa.

\footnotetext{
79 A mayor abundamiento, recientemente, la Tercera Sala de la Corte Suprema, en forma unánime, ha reconocido la plena vigencia de la presunción de inocencia en el derecho administrativo sancionador. Sociedad de ingeniería y certificación de calidad Ltda. (2021).

${ }^{80} \mathrm{Sin}$ perjuicio de los cuestionamientos que se expresarán a continuación, estos argumentos también resultan idóneos para defender la aplicación con matices de la presunción de inocencia en sede administrativa. Al respecto, dado que, como se demostrará en la siguiente sección, es posible reducir las indeterminaciones de los matices, lo cuestionable es más bien la vigencia, en los mismos términos que en el proceso penal, de la presunción de inocencia en el derecho administrativo sancionador.

$81 \mathrm{Ho} 2012,277-279$.

82 FerRajoli 1995, 731-732.
} 
En ese sentido, una aplicación de la presunción de inocencia en los procedimientos administrativos sancionadores, en los mismos términos que en el proceso penal, parece no considerar estas particularidades de los primeros.

En segundo lugar, respecto a los argumentos basados en el común origen o en las similitudes entre las sanciones administrativas y las sanciones penales (iii y iv), cabe recordar que de ellos no se sigue necesariamente la obligación de someter a ambas sanciones a un mismo régimen jurídico ${ }^{83}$. De hecho, la identidad de régimen jurídico ni siquiera es estricta en materia penal. Dos ejemplos ilustran esta situación. Por un lado, el estatuto de responsabilidad penal adolescente, a diferencia del derecho penal de adultos, contempla como principio rector el interés superior del adolescente (artículo 2 Ley $\mathrm{N}^{\circ}$ 20.084). Por otro lado, la diversidad de procedimientos penales establecidos por el legislador para el juzgamiento de los delitos y faltas (procedimiento ordinario, procedimiento abreviado, procedimiento simplificado y procedimiento monitorio). Por lo tanto, si en el ámbito penal-que supone la más intensa afectación de los derechos de una persona- se permiten las diferencias de régimen jurídico, con mayor razón deberían permitirse las diferencias regulativas entre diversos tipos de sanciones administrativas y entre las sanciones administrativas y las sanciones penales.

Por último, la aplicación de la presunción de inocencia en el derecho administrativo sancionador, en los mismos términos que en el proceso penal, conlleva un riesgo de impunidad. Ello ocurriría si se siguiera estrictamente la tesis del ius puniendi único en materia de estándar de prueba. Según esta tesis, la Administración -al igual que los jueces penales- debería absolver al investigado en caso de tener una duda razonable sobre la ocurrencia de los hechos o sobre su responsabilidad en los mismos (artículo 340 Código Procesal Penal). Este alto estándar de prueba, vigente en materia penal, repartiría inequitativamente entre la Administración y el administrado el riesgo de error $^{84}$ y tornaría ineficiente e ineficaz el ejercicio de la potestad sancionadora. Por ejemplo, en el ámbito regulatorio donde la Administración actúa para corregir fallas de mercado ${ }^{85}$, y no se percibe una asimetría de poder entre el particular y la Administración ${ }^{86}$, el estándar de la duda razonable dificultaría la efectiva sanción de las infracciones. Y si las sanciones no se aplican, su poder disuasorio se ve mermado y se favorece la comisión de ilícitos que atentan contra el bienestar general (por ejemplo, el correcto funcionamiento de los mercados).

Ahora bien, estos cuestionamientos a la vigencia de la presunción de inocencia, en los mismos términos que en el proceso penal, en el derecho administrativo sancionador, no deben conducir a descartar su procedencia. Ciertamente pudiera argüirse nuevamente que, en materia administrativa,

\footnotetext{
83 Letelier Wartenberg 2017, 633.

84 Ibíd., 643.

85 Cordero Quinzacara 2013, 120-142; Letelier Wartenberg 2017, 674.

86 Duce Julio 2018, 93.
} 
comúnmente las sanciones recaen sobre el patrimonio del infractor, no sobre su libertad personal, por lo que no es necesaria la presunción de inocencia. Sin embargo, aunque ello es efectivo, se debe considerar que algunas sanciones administrativas patrimoniales no son para nada leves (por ejemplo, la clausura definitiva, la revocación de una autorización o permiso o la disolución de una persona jurídica), pudiendo su gravedad incluso superar la de las sanciones penales patrimoniales, lo que en el caso de las multas resulta bastante elocuente ${ }^{87}$. Luego, si las garantías de un procedimiento se deben establecer en atención a la gravedad de las consecuencias jurídicas respecto de las cuales se decide, entonces se justifica la aplicación de la presunción de inocencia en el derecho administrativo sancionador, al igual que ocurre en los procesos penales en que se imponen sanciones patrimoniales.

A mayor abundamiento, no solo en el ámbito penal (a través de la presunción de inocencia), sino también en materia civil, donde igualmente se discuten controversias que afectan el patrimonio de los particulares, nuestro derecho presume, de modo general, la actuación correcta o conforme a derecho (artículo 707 Código Civil ${ }^{88}$ ). En ese contexto, sería particularmente extraño, desde el punto de vista sistemático, que el derecho administrativo sancionador fuera la excepción y presumiera absolutamente lo contrario (la ilicitud).

Finalmente, prescindir de la presunción de inocencia en el derecho administrativo sancionador llevaría a entender que nuestro Estado democrático de derecho desconfía de los particulares y, por tanto, presumiría su obrar ilícito, conclusión que no se condice con las libertades (de enseñanza, de asociación, de ejercer actividades económicas, de fundar medios de prensa, etc.) y la autonomía (artículo 1 inciso tercero) que el propio texto constitucional les reconoce. Es decir, si el Estado y la Constitución desconfiara de la actividad privada no le reconocería a las personas amplios márgenes de autonomía para el desarrollo de actividades económicas, sociales o culturales, como la prestación de servicios básicos (electricidad, agua potable, entre otros), desde luego bajo el cumplimiento de las disposiciones legales y reglamentarias pertinentes. Como ello no ocurre, cabe afirmar que nuestra Constitución respalda la vigencia matizada de la presunción de licitud o inocencia en el derecho administrativo sancionador como una garantía del debido procedimiento sancionador.

\footnotetext{
87 De acuerdo con el artículo 501 del Código Penal las autoridades administrativas no deberían aplicar mayores sanciones que las previstas respecto de las faltas (multa de diez unidades tributarias mensuales), a menos que una ley especial establezca lo contrario. No obstante, en la práctica, las excepciones al artículo 501, previstas en leyes administrativas sectoriales relativas al medioambiente, la provisión de servicios básicos o los mercados financieros, se han multiplicado y se han convertido en la regla general. Por ejemplo, en materia de servicios eléctricos, el monto en abstracto de las multas puede llegar a diez mil unidades tributarias anuales (artículo 16 Ley $N^{\circ}$ 18.410). En cambio, en materia financiera, el monto de la multa puede alcanzar, según el caso, el doble de los beneficios obtenidos producto de la emisión, registro contable u operación irregular (artículo 36 Decreto Ley N³.538).

88 "La buena fe se presume, excepto en los casos en que la ley establece la presunción contraria. En todos los otros la mala fe deberá probarse".
} 


\section{Los matices en la aplicación de la presunción de inocencia en los procedimientos administrativos sancionadores}

Frente a este escenario, entre una prescindencia de la presunción de inocencia o su aplicación en los mismos términos que en el proceso penal, parece prudente la solución intermedia que consistiría en aplicar con matices la presunción de inocencia en los procedimientos administrativos sancionadores, en virtud de consideraciones de eficiencia y eficacia y a ciertas particularidades de la actividad administrativa. Al respecto los matices deben entenderse como una distinta aplicación de los aspectos secundarios de este derecho, sin alterar su esencia o núcleo ${ }^{89}$. En consecuencia, en el derecho administrativo la presunción de inocencia no es un derecho absoluto, por tanto, puede ponderarse a fin de satisfacer o proteger otros fines constitucionalmente legítimos (por ejemplo, la eficiencia y la eficacia de la Administración), y así matizar sus aspectos secundarios (no sus principales) ${ }^{90}$.

Como ya se expuso, la presunción de inocencia presenta tres significados o manifestaciones principales (regla de trato, regla sobre la carga de la prueba formal y regla sobre la carga de la prueba material o el estándar probatorio). Todos estos significados, de modo general, resultan aplicables en el derecho administrativo sancionador con los matices que se precisarán a continuación.

En lo tocante a la regla de trato, esta se traduce en el deber de los órganos administrativos y de los tribunales de justicia de considerar al investigado como inocente. Esta obligación rige desde el inicio del procedimiento administrativo sancionador hasta la entrada en vigencia de la resolución san-

89 GÓmez TOMillo 2020, 19.

90 Los aspectos principales de la presunción de inocencia no se deberían ponderar en el derecho administrativo sancionador, ni siquiera respecto de ilícitos o infracciones graves. Precisamente, tratándose de una infracción grave, las sanciones administrativas aplicables son las más rigurosas. En ese contexto, se justifica que el estándar de garantías del procedimiento sancionador sea el más alto, no el más bajo. Sin perjuicio de ello, en cuanto a la regla de trato, desde el punto de vista sistemático, sería inconsistente o incoherente que, por ejemplo, en un mismo procedimiento sancionador, respecto de una infracción gravísima, se considere al administrado como culpable, y respecto de una infracción leve ello no ocurra. Tampoco se podría adelantar la imposición de la sanción sin haber ni siquiera una resolución sancionadora, pues ello resultaría contrario al derecho de defensa. Respecto de la asignación de la carga de la prueba, incluso en materia civil (art. 1698 Código Civil), donde también se discuten controversias patrimoniales, quien afirma un hecho debe probarlo. Por ello, en materia sancionadora administrativa, quien formula los cargos y pretende alterar el statu quo (la Administración), por ejemplo, imponiendo la obligación de pago de una determinada suma de dinero (sanción de multa), debe aportar pruebas que sustenten su pretensión. En cambio, el particular, si procura controvertir la pretensión administrativa, aseverando, por ejemplo, la prescripción de la infracción, debe proporcionar prueba de sus defensas. Por último, quien debe soportar la insuficiencia de prueba (carga de la prueba material), es la parte a quien correspondía probar un hecho, por lo que sería particularmente extraño hacer recaer esta deficiencia en la otra parte. Por ejemplo, si se entendiera que la Administración debe absolver al administrado porque este último no aportó prueba de un caso fortuito; o si se defendiera que la Administración debe condenar al particular pese a que las pruebas no han logrado superar el estándar de la probabilidad preponderante (la decisión carecería de racionalidad). 
cionadora. Es decir, a diferencia de la regulación penal, no se requeriría esperar a que se encuentre firme la sentencia que resuelva la reclamación judicial de la resolución sancionadora, pues esta sería inmediatamente ejecutable en virtud de la presunción de legalidad del acto administrativo (artículo 3 inciso final Ley $N^{\circ}$ 19.880). En lo demás, nada impediría a la autoridad administrativa adoptar medidas cautelares o provisionales dentro del procedimiento administrativo sancionador, siempre que se verifiquen sus presupuestos o requisitos. Estas medidas, que no afectan la libertad personal del administrado, no deberían considerarse una sanción anticipada.

Respecto a la regla sobre la distribución de la carga de la prueba formal, esta establece a cuál de las partes corresponde aportar pruebas sobre un determinado hecho. Al respecto en materia administrativa sancionadora se debe distinguir. Por un lado, la prueba de los hechos, la participación del presunto infractor y las agravantes de responsabilidad corresponderá a la Administración. Por otro lado, la prueba de los hechos excluyentes o extintivos y las atenuantes de responsabilidad, tales como el caso fortuito, la fuerza mayor, la diligencia debida, la prescripción de la infracción y la subsanación de la misma, recaerá sobre el administrado91. Sobre este punto no hay mayores variaciones en relación con la regulación penal de la presunción de inocencia.

Un aspecto que sí presenta conflictos con la presunción de inocencia en el derecho administrativo sancionador es el relativo a las presunciones de responsabilidad o la inversión de la carga de la prueba en perjuicio del infractor. Al respecto se presentan dos situaciones que podrían desdibujar la presunción de inocencia. Por una parte, las presunciones de responsabilidad, por ejemplo, la conducción bajo la influencia del alcohol en los accidentes de tránsito ${ }^{92}$. Por otra parte, las más frecuentes, presunciones legales de veracidad de los hechos constatados en las actas de fiscalización ${ }^{93}$.

En lo que respecta a las primeras (presunciones de responsabilidad), se debe recordar que en materia administrativa rige un sistema de libre valoración de la prueba o según la sana crítica (artículo 35 Ley N¹9.880), por lo

\footnotetext{
91 Gómez Tomillo y Sanz Rubiales 2017, 807-832.

92 El artículo 167 de la Ley N 18.290 establece un catálogo de presunciones de responsabilidad del conductor en los accidentes de tránsito, entre ellas: conducir un vehículo sin haber obtenido la licencia correspondiente o encontrándose esta cancelada o adulterada; conducir contra el sentido de la circulación; y, conducir en condiciones físicas deficientes o bajo la influencia del alcohol o de estupefacientes o sustancias sicotrópicas.

93 Por ejemplo, el artículo 52 de la Ley No 20.529 establece que: "Para los efectos de la esta ley el personal de la Superintendencia [de Educación] habilitado como fiscalizador tendrá también el carácter de ministro de fe respecto de todas las actuaciones que realice en el ejercicio de sus funciones y que consten en el acta de fiscalización, dentro de las cuales podrá tomar declaraciones bajo juramento.

Los hechos constatados por los funcionarios y sobre los cuales deban informar, de oficio o a requerimiento, podrán constituir presunción legal de veracidad para todos los efectos de la prueba judicial".

En un sentido similar, refiriéndose a una presunción legal, artículo 3 D Ley N ${ }^{\circ} 18.410$, artículo 11 A Ley $N^{\circ} 18.902$ y artículo 8 inciso segundo Ley $N^{\circ} 20.417$.
} 
que estas presunciones no predeterminan el valor o la fuerza de las pruebas. Asimismo, estas presunciones no liberan a la Administración de la necesidad de aportar pruebas que acrediten el hecho base, por ejemplo, que el conductor manejaba su vehículo bajo la influencia del alcohol al momento del accidente. El efecto de estas presunciones radica en la inversión de la carga de la prueba, la que se traslada al infractor incentivándole a aportar pruebas de descargo si desea evitar la sanción. Es decir, en este punto habría un matiz respecto de cómo opera la presunción de inocencia en el proceso penal, diferenciación que no es arbitraria sino fundada en razones epistémicas y en consideraciones de eficiencia y eficacia (facilitación probatoria). En efecto, comúnmente las presunciones legales de responsabilidad en el derecho administrativo sancionador se fundan en máximas de la experiencia, esto es, en juicios hipotéticos de carácter general acerca de lo que ocurre en muchos ca$\operatorname{sos}^{94}$. De ahí que, mientras persistan las razones epistémicas y de facilitación probatoria detrás de las presunciones legales de responsabilidad (las cuales por lo demás admiten prueba en contrario), ellas pueden convivir con la presunción de inocencia en el derecho administrativo sancionador.

El caso de las presunciones de legalidad de los hechos constatados por funcionarios públicos que revisten la calidad de ministros de fe, también admitiría una interpretación conforme con la presunción de inocencia. Para Larroucau Torres ${ }^{95}$, por ejemplo, los preceptos sobre los hechos establecidos en las actas de fiscalización no se refieren a una auténtica presunción sino a reglas de peso probatorio. Estas reglas de peso probatorio graduarían el nivel de confiabilidad que tienen las actas de fiscalización, al mismo tiempo que permitirían controvertir su contenido tanto dentro del procedimiento administrativo sancionador como en la reclamación judicial posterior. De todos modos, el mismo autor reconoce que la terminología empleada por el legislador es confusa (oscurece el rol que cumplen las reglas de peso probatorio) y que, en la práctica, es muy improbable derrotar las actas de fiscalización ${ }^{96}$.

Efectivamente, las actas de fiscalización pueden entenderse como uno de los medios de prueba que tendrá que aportar la Administración para acreditar los hechos y la responsabilidad del infractor. Asimismo, al regir un sistema de libre valoración, la autoridad que imponga la sanción o el juez que conozca de la reclamación en contra de la resolución sancionadora, puede, a partir de otras pruebas, arribar a una conclusión diversa a la consignada en el acta de fiscalización. Sin embargo, debe considerarse que las actas de

\footnotetext{
94 Couture Etcheverry 1958, 229-230.

95 Larroucau Torres 2020, 170-186.

96 Jara Schnettler y Maturana Miquel 2009, 26, por su parte, plantean otra interpretación conforme con la presunción de inocencia. Las actas de fiscalización no serían una forma de prueba tasada, sino que solo un antecedente probatorio de cargo que, por sí solo, no sería suficiente para destruir la presunción de inocencia del infractor. Además, el valor probatorio de las actas de fiscalización quedaría condicionado al cumplimiento de ciertos requisitos: imparcialidad, objetividad, percepción personal y directa y ratificación posterior del fiscalizador dentro del procedimiento sancionador.
} 
fiscalización, por sí solas, constituyen una prueba suficiente para sancionar al administrado97. Por lo que, las reglas sobre las actas de fiscalización, aunque no serían una presunción y serían derrotables, en la práctica operan de manera similar a una presunción ya que incentivan al administrado a rendir prueba que desvirtúe los hechos consignados en ellas. Nuevamente, en este punto habría un matiz o diferencia respecto de la forma en que opera la presunción de inocencia en los procedimientos sancionadores en comparación con los procesos penales.

Finalmente, la regla de juicio, o regla sobre la carga de la prueba material, se dirige a la autoridad encargada de resolver un procedimiento administrativo sancionador, instruyéndole que haga recaer sobre la parte a quien correspondía probar un hecho las consecuencias de la falta o insuficiencia de prueba. Como se señaló, la presunción de inocencia como regla de juicio, para ser operativa presupone un estándar de prueba, con independencia de cuál sea su contenido ${ }^{98}$. Al respecto las leyes sectoriales no han fijado un umbral de suficiencia probatoria para aplicar sanciones administrativas. En ese escenario, correspondería a la doctrina y a la jurisprudencia realizar esta labor.

Desde luego, una regla sobre el estándar de prueba, en el marco de un sistema de libre valoración de la prueba, resulta necesaria en los procedimientos administrativos sancionadores, pues ella se vincula con la motivación y la impugnación de los actos administrativos, entre ellos, los que aplican sanciones. Es decir, si no hubiera una regla sobre el estándar de prueba, el presunto infractor no podría saber cuál es el umbral de suficiencia exigible para tener por probada una proposición sobre los hechos en el procedimiento administrativo sancionador, ni tampoco el juez o tribunal que conozca de la impugnación de la resolución sancionadora podría controlar la motivación fáctica de esta99.

En esa línea, en la determinación del estándar de prueba para aplicar sanciones administrativas se debería considerar que las sanciones administrativas inciden generalmente en la esfera patrimonial de sus destinatarios. Por ello, es posible matizar el contenido de la presunción de inocencia en sede administrativa y afirmar que el nivel de suficiencia de las pruebas debería ser menor que el exigido en materia penal ${ }^{100}$. El estándar de prueba para imponer sanciones administrativas debería ser, por regla general, el de la probabilidad preponderante ${ }^{101}$. Este estándar exigiría que se tenga por pro-

\footnotetext{
97 HUERGO LORA 2007, 431.

98 Ferrer Beltrán 2010, 16-20.

99 En un sentido similar, respecto del proceso penal, Accatino ScAgliotti 2011, 484; ReYES 2012, 245-246.

100 Letelier Wartenberg 2017, 641.

101 Ibíd., 645. Tampoco el estándar probatorio en materia administrativa sancionadora podría ser menor que el de la probabilidad preponderante, pues "un estándar menos exigente implicaría que se debiera tener por probada una hipótesis menos corroborada, o, dicho de otro modo, menos probablemente verdadera, que otras hipótesis sostenidas en el proceso, lo que consti-
} 
bada la proposición fáctica que resulte relativamente más corroborada por las pruebas disponibles en el procedimiento administrativo sancionador ${ }^{102}$. Excepcionalmente, tratándose de casos calificados (por ejemplo, la expulsión del territorio nacional por incumplimiento de las normas migratorias en que la sanción afecta la libertad personal del infractor), el estándar de prueba podría ser mayor que la probabilidad preponderante $y$, en todo caso, menor que la duda razonable ${ }^{103}$.

\section{Conclusiones}

La jurisprudencia del TC y de la Corte IDH han sostenido la aplicabilidad del derecho al debido proceso en el ámbito administrativo con base en tres líneas argumentales, ninguna de las cuales resulta del todo satisfactoria. Por ello, debe entenderse que el debido proceso resulta aplicable en materia administrativa como un límite a la arbitrariedad estatal y como un mecanismo de control de la promoción del bien común. En ese sentido, en el ejercicio de sus potestades, la Administración debería respetar un debido procedimiento sustantivo, esto es, ciertas garantías mínimas encaminadas a obtener la dictación de actos administrativos razonables. Estas garantías mínimas, reguladas en la Ley $\mathrm{N}^{\circ} 19.880$, son: la contradicción, la publicidad y la celeridad del procedimiento administrativo y la motivación y la impugnación del acto administrativo.

En un Estado democrático de derecho, el procedimiento administrativo sancionador, en comparación con otros procedimientos administrativos, debe estar rodeado de mayores garantías en favor de los particulares. Estas garantías adicionales constituyen una concreción de los principios de contradictoriedad y de impugnabilidad de los actos administrativos y su contenido coincide con ciertas garantías procedimentales penales, a saber: (i) el derecho a la comunicación previa y precisa de los cargos formulados; (ii) el derecho a conocer, solicitar y participar de las diligencias probatorias; y (iii) el derecho a impugnar la resolución sancionatoria ante un juez o tribunal.

La presunción de inocencia es un derecho humano o fundamental -implícito en nuestra Constitución- que surgió como reacción al proceso penal del Antiguo Régimen. Actualmente, la presunción de inocencia como derecho subjetivo del imputado impone obligaciones a los jueces, a los intervinientes del proceso penal y a la sociedad. Estas obligaciones versan sobre el tratamiento que debe recibir el imputado (regla de trato), la iniciativa probatoria dentro del proceso penal (regla sobre la distribución de la carga de la prueba) y el nivel de suficiencia que debe tener la prueba de cargo (regla sobre el estándar de prueba).

tuiría una directiva incompatible con la exigencia de valoración racional de la prueba". AccATINO SCAGLIOTTI 2011, 486-487.

102 Accatino Scagliotti 2011, 486.

103 Letelier Wartenberg 2018, 224-225; Duce Julio 2018, 91; Isensee Rimassa 2016, 95-96. 
La aplicación de la presunción de inocencia en los procedimientos administrativos sancionadores, en los mismos términos que en el proceso penal, no resulta infundada. Sin embargo, esta tesis no resulta adecuada o conveniente a la luz de otros factores relevantes en esta discusión, entre ellos, la general ausencia de una afectación de la libertad personal y del honor del infractor y el riesgo de comprometer la eficacia disuasiva de las sanciones administrativas.

En este escenario, considerando la gravedad de las sanciones administrativas, la coherencia de nuestro ordenamiento jurídico y la confianza que la Constitución ha depositado en la actividad privada, es posible sostener la aplicación matizada de la presunción de inocencia como una garantía del debido procedimiento sancionador. Esta solución aporta flexibilidad y mantiene intactos los aspectos nucleares o esenciales del derecho a la presunción de inocencia, alterando solo sus aspectos secundarios. Así, la Administración está obligada a tratar como inocente al presunto infractor (núcleo), hasta la entrada en vigencia de la resolución sancionadora (matiz). Asimismo, a la Administración corresponde aportar pruebas sobre los hechos, la participación del administrado y las agravantes de responsabilidad (núcleo), pudiendo valerse de presunciones legales (matiz). Mientras que el administrado asume la carga probatoria de sus defensas. Finalmente, la operatividad de la presunción de inocencia como regla de juicio requiere de un estándar de prueba (núcleo), siendo este, por regla general, el de la probabilidad preponderante (matiz).

\section{Bibliografía citada}

Accatino Scagliottı, D. (2011). Certezas, dudas y propuestas en torno al estándar de la prueba penal. Revista de Derecho Pontificia Universidad Católica de Valparaíso (2), 483-511.

Bermúdez Soto, J. (2014). Derecho Administrativo General. Legal Publishing.

Bordali Salamanca, A. (2016). Derecho Jurisdiccional. Derecho Austral.

Bordali Salamanca, A. (2010). La independencia judicial en el derecho chileno. Legal Publishing.

Boutaud Scheuermann, E. (2018). El debido proceso sustantivo en la jurisprudencia de la Corte Interamericana de Derechos Humanos. Ediciones Jurídicas de Santiago.

Comisión de Estudios de la Nueva Constitución (1975). Sesión 101 T III. En Biblioteca del Congreso Nacional, Antecedentes Constitucionales Constitución de 1080 (T III, pp. 501-538).

Contreras Vasouez, Pablo (2015). Análisis Crítico del Control de Convencionalidad. En M. Núñez Poblete (Ed.), La Internacionalización del Derecho Público (pp. 425-469). Thomson Reuters.

Couture Etcheverry, E. (1958). Fundamentos del Derecho Procesal Civil. Depalma.

Cordero Quinzacara, E. (2014). Los principios que rigen la potestad sancionadora de la Administración en el derecho chileno. Revista de Derecho de la Pontificia Universidad Católica de Valparaíso (1), 399-439.

Cordero Quinzacara, E. (2013). Sanciones administrativas y mercados regulados. Revista de Derecho Universidad Austral de Chile (1), 119-144.

Cuerda Riezu, A. (2014). La prueba de las eximentes en el proceso penal: ¿obligación de la defensa o de la acusación?. Indret (2), 1-18.

DuCE JULIO, M. (2018). Reflexiones sobre el proceso sancionatorio administrativo chileno: debido proceso, estándar de convicción (prueba) y el alcance del sistema recursivo. Diritto Penale Contemporaneo (2), 83-101. 
Duff, A. (2013). Who Must Presume Whom to Be Innocent of What?. Netherlands Journal of Legal Philosophy (3), 170-192.

Enteiche Rosales, N. (2014). Sobre el estatuto penal aplicable a las sanciones administrativas en Chile. Actualidad Jurídica (30), 292-303.

Esparza Leibar, I. (1995). El principio del debido proceso. Bosch.

Fernández LÓPEZ, M. (2004). Presunción de inocencia y carga de la prueba en el proceso penal. Universidad de Alicante.

FerRAJOLI, L. (1995). Derecho y razón. Teoría del garantismo penal. Trotta.

Ferrada Bórouez, J. (2014). La articulación de las potestades administrativas y jurisdiccionales en la aplicación de sanciones administrativas en el derecho chileno: poderes distintos, pero complementarios. En J. Arancibia, P. Alarcón (Eds.), Sanciones Administrativas (pp. 239-261). Thomson Reuters.

FerRADA BÓRQuez, Juan (2011). Los tribunales que ejercen la justicia administrativa en el derecho chileno. J. Arancibia, J. Martínez, A. Romero (Eds.), Litigación Pública (pp. 119-150). Thomson Reuters.

Ferrer Beltrán, J. (2010). Una concepción minimalista y garantista de la presunción de inocencia. Revista de la Maestría en Derecho Procesal (1), 1-26.

Gómez Tomillo, M. y Sanz Rubiales, Í. (2017). Derecho administrativo sancionador. Parte General. Aranzadi.

Gordillo, A. (2013). Tratado de Derecho Administrativo y obras selectas. Parte General (T I). Fundación De Derecho Administrativo.

Ho, H. (2012). The Presumption of Innocence as a Human Right. En P. Roberts y J. Hunter (Eds.), Criminal Evidence and Human Rights (pp. 259-281). Hart Publishing.

Horvitz Lennon, M. y López Masle, J. (2002). Derecho procesal penal chileno (T I). Editorial Jurídica de Chile.

HUERgo LoRA, A. (2007). Las sanciones administrativas. lustel.

Hunter Ampuero, I. (2015). La carga de la prueba en el contencioso administrativo ambiental chileno: notas a propósito de la ley de tribunales ambientales. Revista Chilena de Derecho (2), 649-669.

ISENSEE RIMASSA, C. (2016). Debido proceso y su recepción en la Ley Nº 19.880: valoración y estándar de prueba en sede administrativa. Revista de Derecho Público (84), 85-97.

Jara Schnettler, J. y Maturana Miquel, C. (2009). Actas de fiscalización y debido procedimiento administrativo. Revista de Derecho Administrativo (3), 1-28.

Larroucau Torres, J. (2020). Las reglas de peso probatorio como privilegio de la potestad sancionadora de la Administración del Estado. lus et Praxis (2), 170-192.

Letelier Wartenberg, R. (2018). El precio del statu quo. Sobre el estándar probatorio en las sanciones administrativas. Revista de Derecho (Universidad Austral de Chile) (1), 209-229.

Letelier Wartenberg, R. (2017). Garantías penales y sanciones administrativas. Política Criminal (24), 622-689.

Nogueira Alcala, H. (2005). Consideraciones sobre el derecho fundamental a la presunción de inocencia. lus et Praxis (1), 221-241.

Nogueira AlcalA, H. (2003). La constitucionalización del proceso: el acceso a la jurisdicción, tutela judicial efectiva o debido proceso. En J. Ferrada Bórquez (Coord.), La constitucionalización del derecho chileno (pp. 169-207). Editorial Jurídica de Chile.

Reyes Molina, S. (2012). Presunción de inocencia y estándar de prueba en el proceso penal: Reflexiones sobre el caso chileno. Revista de Derecho Universidad Austral de Chile (2), pp. 221-241.

RomÁn CoRDERO, C. (2014). El debido procedimiento administrativo sancionador. Revista de Derecho Público (71), 183-214.

Valenzuela Saldías, J. (2011). Presumir responsabilidad: sobre una relación entre la prisión preventiva y la presunción de inocencia en el derecho procesal chileno. Revista Estudios de la Justicia (14), pp. 53-70.

Van Weezel De la Cruz, Alex (2017). Sobre la necesidad de un cambio de paradigma en el derecho sancionatorio administrativo. Política Criminal (24), 997-1043. 
Vergara Blanco, A. (2004). Esquema de los principios del Derecho Administrativo Sancionador. Revista de Derecho Universidad Católica del Norte (2), 137-147.

Williams, R. (2010). The One and Only Substantive Due Process Clause. Yale Law Journal (3), 408-512.

Zapata LarRaín, P. (2008). Justicia Constitucional: Teoría y práctica en el derecho chileno y comparado. Editorial Jurídica de Chile.

\section{Normativa citada}

Código Penal. 12 de noviembre de 1874 (Chile).

Convenio Europeo para la Protección de los Derechos Humanos y de las Libertades Fundamentales. 4 noviembre 1950.

Decreto N ${ }^{\circ} 873$ de 1990 [Ministerio de Relaciones Exteriores]. Convención Americana de Derechos Humanos, adoptada con fecha 22 de noviembre de 1969. 23 de agosto de 1990.

Declaración de los Derechos del Hombre y del Ciudadano. 26 agosto 1789.

Decreto $N^{\circ} 1$ [con fuerza de ley]. Fija texto refundido, coordinado y sistematizado del Código Civil. D.O. N 36.676.

Decreto $N^{\circ} 1$ [con fuerza de ley]. Fija texto refundido, coordinado y sistematizado de la Ley de Tránsito. 27 de diciembre de 2007. D.O. N³9.498.

Decreto $N^{\circ} 1-19653$ [con fuerza de ley]. Fija texto refundido, coordinado y sistematizado de la Ley N 18.575, orgánica constitucional de Bases Generales de la Administración del Estado. 13 de diciembre 2000. D.O. N 37.137.

Decreto $\mathrm{N}^{\circ} 3$ [con fuerza de ley]. Fija texto refundido, coordinado y sistematizado de la Ley de Propiedad Industrial. 9 de marzo de 2006. D.O. N 38.493.

Decreto $N^{\circ} 3.538$ [Ministerio de Hacienda]. Crea la Comisión para el Mercado Financiero. 9 de diciembre de 1980. D.O. $\mathrm{N}^{\circ} 30.847$.

Ley $N^{\circ} 10.336$ de 1952. Fija el texto refundido de la ley de organización y atribuciones de la Contraloría General de la República. 12 de mayo de 1952. D.O. N²2.261.

Ley $N^{\circ} 18.410$ de 1985. Crea la Superintendencia de Electricidad y Combustibles. 26 de abril de 1985. D.O. N $N^{\circ} 32.176$.

Ley $N^{\circ} 18.902$ de 1989. Crea la Superintendencia de Servicios Sanitarios. 8 de enero de 1989. D.O. No 33.581.

Ley N 19.696 de 2000. Establece Código Procesal Penal. 29 de septiembre de 2000. D.O. $N^{\circ} 36.785$.

Ley $N^{\circ} 19.880$ de 2003. Establece Bases de los Procedimientos Administrativos que rigen los actos de los órganos de la Administración del Estado. 22 de mayo de 2003. D.O. $\mathrm{N}^{\circ} 37.570$.

Ley $\mathrm{N}^{\circ} 20.084$ de 2005. Establece un sistema de responsabilidad de los adolescentes por infracciones a la ley penal. 28 de noviembre de 2005. D.O. N 38.331.

Ley N $N^{\circ} 20.417$ de 2010. Crea el Ministerio, el Servicio de Evaluación Ambiental y la Superintendencia del Medio Ambiente. 12 de enero de 2010. D.O. No 39.570.

Ley N 20.529 de 2011. Sistema Nacional de Aseguramiento de la Calidad de la Educación Parvularia, Básica y Media y su fiscalización. 11 de agosto de 2011. D.O. № 40.046.

Ley N 27.444 de 2001. Ley de Procedimiento Administrativo General. El Peruano, 11 abril de 2001.

\section{Jurisprudencia citada}

Corte I. D. H., Garantías judiciales en estados de emergencia. Opinión Consultiva OC-9/87 del 6 de octubre de 1987.

Corte I. D. H., Caso del Tribunal Constitucional vs. Perú, del 31 de enero de 2001. Serie Serie C N 55 y 71.

Corte I. D. H., Caso Baena Ricardo y otros vs. Panamá, del 2 de febrero de 2001. Serie C $N^{\circ} 61,72$ y 104. 
Corte I. D. H., Caso Ivcher Bronstein vs. Perú, del 6 de febrero de 2001. Serie C N 54, 74 y 84. Corte I. D. H., Caso Vélez Loor vs. Panamá, del 23 de noviembre de 2010. Serie C N²18. Corte I. D. H., Caso Zegarra Marín vs. Perú, del 15 de febrero de 2017. Serie C Nº 331.

Corte I. D. H., Caso Acosta y otros vs. Nicaragua, del 25 de marzo de 2017. Serie C No 334. Megamedia S.A. con Consejo Nacional de Televisión (2021): Corte Suprema, 17 de mayo de 2021 (Rol No 7020-2021). Tercera Sala. [Recurso de Queja].

Sociedad de ingeniería y certificación de calidad Ltda. con Superintendencia de Electricidad y Combustibles (2021): Corte Suprema, 9 de agosto de 2021 (Rol 36698-2021). Tercera Sala. [Recurso de Reclamación].

Requerimiento de inconstitucionalidad formulado por doce señores Senadores respecto del proyecto de ley que modifica el Decreto con Fuerza de Ley $N^{\circ} 458$, de 1975, Ley General de Urbanismo y Construcciones (2005): Tribunal Constitucional, 21 de abril de 2005 (Rol No 437-05). Pleno.

Requerimiento de inaplicabilidad por inconstitucionalidad presentado por Sergio Abraham Salinas Pérez, respecto de los artículos 6, letra B) No 6, y 115 del Código Tributario y 19, letra b), del Decreto con Fuerza de Ley $N^{\circ} 7$ de 1980, Ley Orgánica del Servicio de Impuestos Internos en la causa rol No 10.439-2006, seguida ante la Dirección Regional de Impuestos Internos (2007): Tribunal Constitucional, 6 de septiembre de 2007 (Rol No 616-06). Segunda Sala.

Solicitud de la Corte de Apelaciones de Talca, para que se emita un pronunciamiento acerca de la eventual inaplicabilidad de los artículos 6, letra B No 3 y 6; 107 y 161 del Código Tributario, en causa Rol Corte $N^{\circ}$ 59.648-60.264, acumuladas (2008): Tribunal Constitucional, 26 de junio de 2008 (Rol No 725-07). Primera Sala.

Requerimiento presentado por un grupo de Diputados sobre la inconstitucionalidad de disposiciones del proyecto de ley contenido en el Boletín $N^{\circ} 3953-04$, que introduce modificaciones al Decreto con Fuerza de Ley N² 2, de 1998, del Ministerio de Educación, que aprueba el texto refundido, coordinado y sistematizado de la ley sobre subvención del Estado a establecimientos educacionales (2007): Tribunal Constitucional, 25 octubre 2007 (Rol No 771-07). Pleno

Requerimiento de inaplicabilidad por inconstitucionalidad de María Angélica Sánchez Vogel y otros, respecto del artículo 169 del Código Sanitario, en recurso de amparo rol No 3073 - 2009 de la Corte de Apelaciones de Santiago (2010): Tribunal Constitucional, 21 de octubre de 2010 (Rol No 1518-09). Segunda sala.

Requerimiento de inaplicabilidad por inconstitucionalidad presentado por CGE Distribución S.A. respecto del artículo 15, inciso primero, de la Ley $N^{\circ} 18.410$, que crea la Superintendencia de Electricidad y Combustibles, en los autos sobre reclamación de ilegalidad, caratulados CGE Distribución S.A. con Superintendencia de Electricidad y Combustibles, de que conoce la Corte de Apelaciones de Santiago, bajo el Rol No 4322-2012 (2013): Tribunal Constitucional, 24 de octubre de 2013 (Rol No 2264-12). Primera Sala.

Requerimiento de inaplicabilidad por inconstitucionalidad presentado por Aldo Motta Camp respecto del precepto legal contenido en el inciso segundo del artículo 35 de la Ley $N^{\circ} 19.880$, en aquella parte que dispone "cuando a la Administración no le consten los hechos alegados por los interesados o la naturaleza del procedimiento que exija", en los autos caratulados "Motta Camp Aldo con Superintendencia de Valores y Seguros", sobre reclamo de ilegalidad de que conoce la Corte de Apelaciones de Santiago, bajo el Rol No Civil-4359-2014 (2014): Tribunal Constitucional, 30 de octubre de 2014 (Rol No 2682-14). Segunda Sala.

Requerimiento de inaplicabilidad por inconstitucionalidad presentado por el Banco de Crédito e Inversiones respecto de los artículos 289, letra a) y 292, inciso primero, del Código del Trabajo y del artículo $4^{\circ}$, inciso primero, parte final, de la Ley $N^{\circ} 19.886$, en los autos sobre recurso de queja, caratulados "Inspección Provincial del Trabajo de Santiago con Banco de Crédito e Inversiones S.A.", de que conoce la Corte Suprema, bajo el Rol No 22.939-2014 (2015): Tribunal Constitucional, 15 de octubre de 2015 (Rol $\left.N^{\circ} 2722-14\right)$. Segunda sala. 
Requerimiento de inaplicabilidad por inconstitucionalidad presentado por Salmones Caleta Bay S.A. respecto a la oración final del tercer párrafo del $N^{\circ} 1$ del artículo 125 de la Ley No 18.892 Ley General de Pesca y Acuicultura, que establece que "La denuncia así formulada, constituirá presunción de haberse cometido la infracción", en los autos sobre recurso de apelación caratulados "Servicio Nacional de Pesca y Acuicultura Región de Los Lagos con Salmones Caleta Bay S.A.", ingreso Rol N Civil-132-2018, de la Corte de Apelaciones de Valdivia (2019): Tribunal Constitucional, 13 de junio de 2019 (Rol $\mathrm{N}^{\circ}$ 4446-18). Primera sala.

Requerimiento de inaplicabilidad por inconstitucionalidad presentado por Pesquera Centro Sur Spa, respecto de la frase "La denuncia así formulada, constituirá presunción de haberse cometido la infracción", contenida en el artículo 125, numeral 1), tercer párrafo de la Ley General de Pesca y Acuicultura, en los autos caratulados "SERNAPESCA con Pesquera Centro Sur SPA", sobre recurso de apelación, de que conoce la Corte de Apelaciones de Concepción, bajo el Rol N³0-2019 (2019): Tribunal Constitucional, 26 de noviembre de 2019 (Rol No 6437-19). Segunda sala.

Requerimiento de inaplicabilidad por inconstitucionalidad presentado por Luis Alberto Poblete Novoa, respecto del artículo 125, numeral 1), párrafo cuarto, de la Ley $N^{\circ} 18.892$, General de Pesca y Acuicultura, en los autos caratulados "Servicio Nacional de Pesca y Acuicultura con Luis Alberto Poblete Novoa", de que conoce la Corte Suprema, por recurso de casación en el fondo, bajo el Rol N²3129-2019 (2020): Tribunal Constitucional, 14 de enero de 2020 (Rol N 7318-19). Segunda Sala.

Requerimiento de inaplicabilidad por inconstitucionalidad presentado por Manuel Jesús Bello Isla, respecto de la oración final del tercer párrafo del numeral primero del artículo 125 de la Ley General de Pesca y Acuicultura, que prescribe: La denuncia así formulada, constituirá presunción de haberse cometido la infracción, en los autos Rol Corte Civil No 855-2020, sobre recurso de apelación, de que conoce la Corte de Apelaciones de Concepción (2020): Tribunal Constitucional, 15 de septiembre de 2020 (Rol $N^{\circ}$ 8696-20). Segunda Sala.

Cuestiones de inconstitucionalidad promovidas por la Sección Quinta de la Sala de lo Contencioso-Administrativo del Tribunal Superior de Justicia de Cataluña, la Sala de lo Contencioso-Administrativo del Tribunal Superior de Justicia de Cantabria y la Sala de lo Contencioso-Administrativo del Tribunal Superior de Justicia de Castilla y León (1995): Tribunal Constitucional España, 21 de diciembre de 1995 ( $N^{\circ}$ 197). Pleno. 